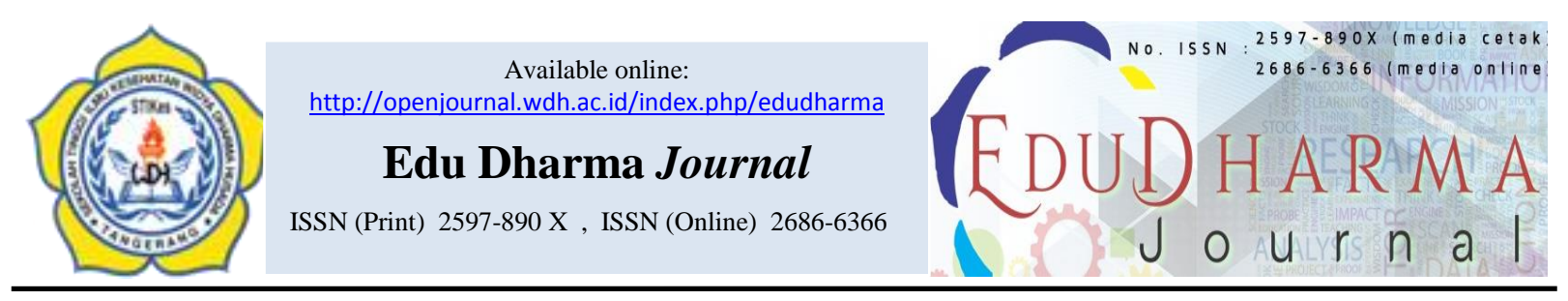

\title{
HUBUNGAN PENGETAHUAN DAN POLA ASUH ORANG TUA TERHADAP PERILAKU SEKSUAL PADA MAHASISWA REKAM MEDIS STIKES KHARISMA PERSADA
}

\author{
Putri Handayani Setyaningsih ${ }^{1 *}$, Olivia Maharani Saputri ${ }^{2}$ \\ ${ }^{1,2}$ STIKes Widya Dharma Husada Tangerang, Jalan Pajajaran No.1, Pamulang, Tangerang Selatan 15417, Indonesia
}

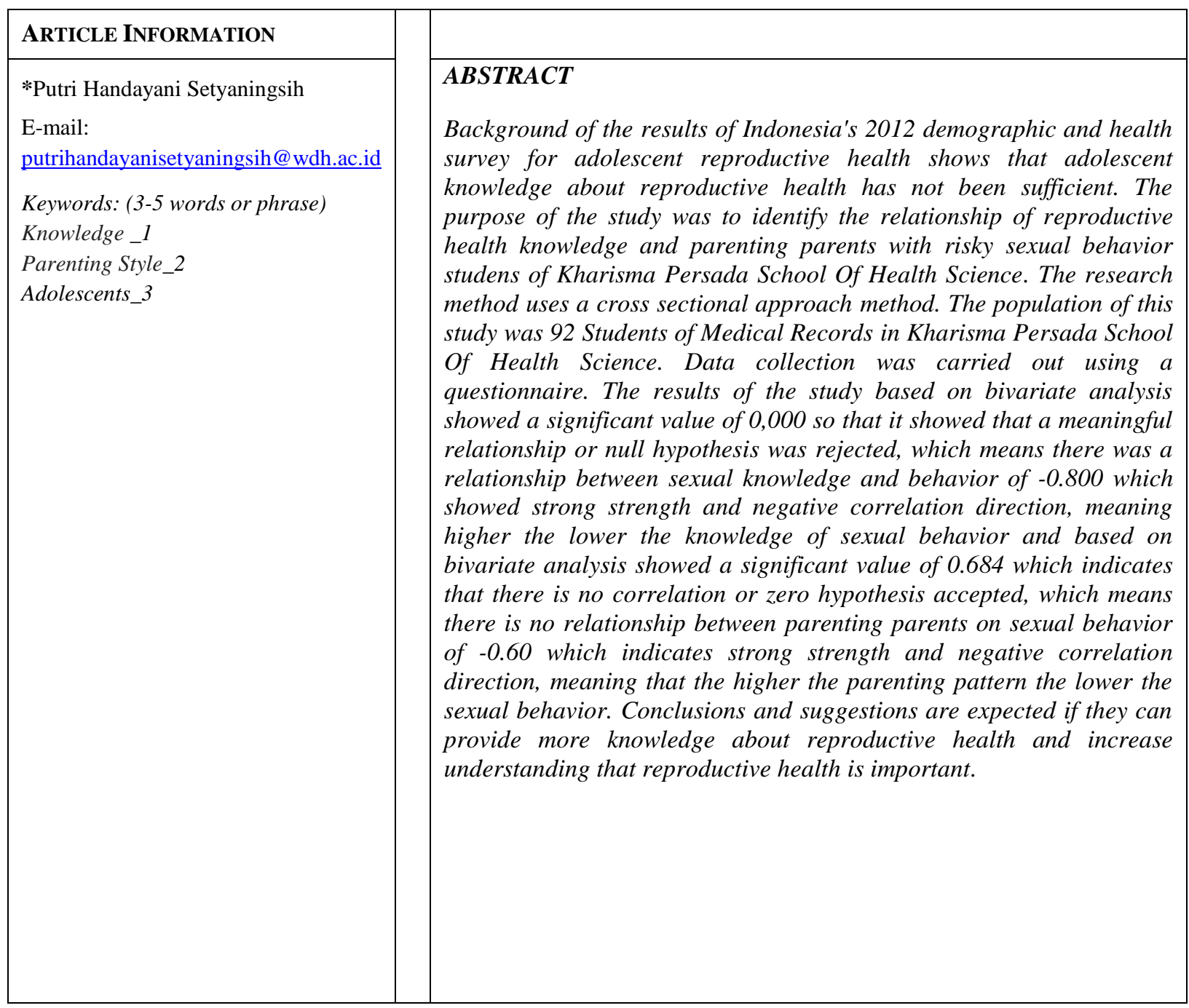




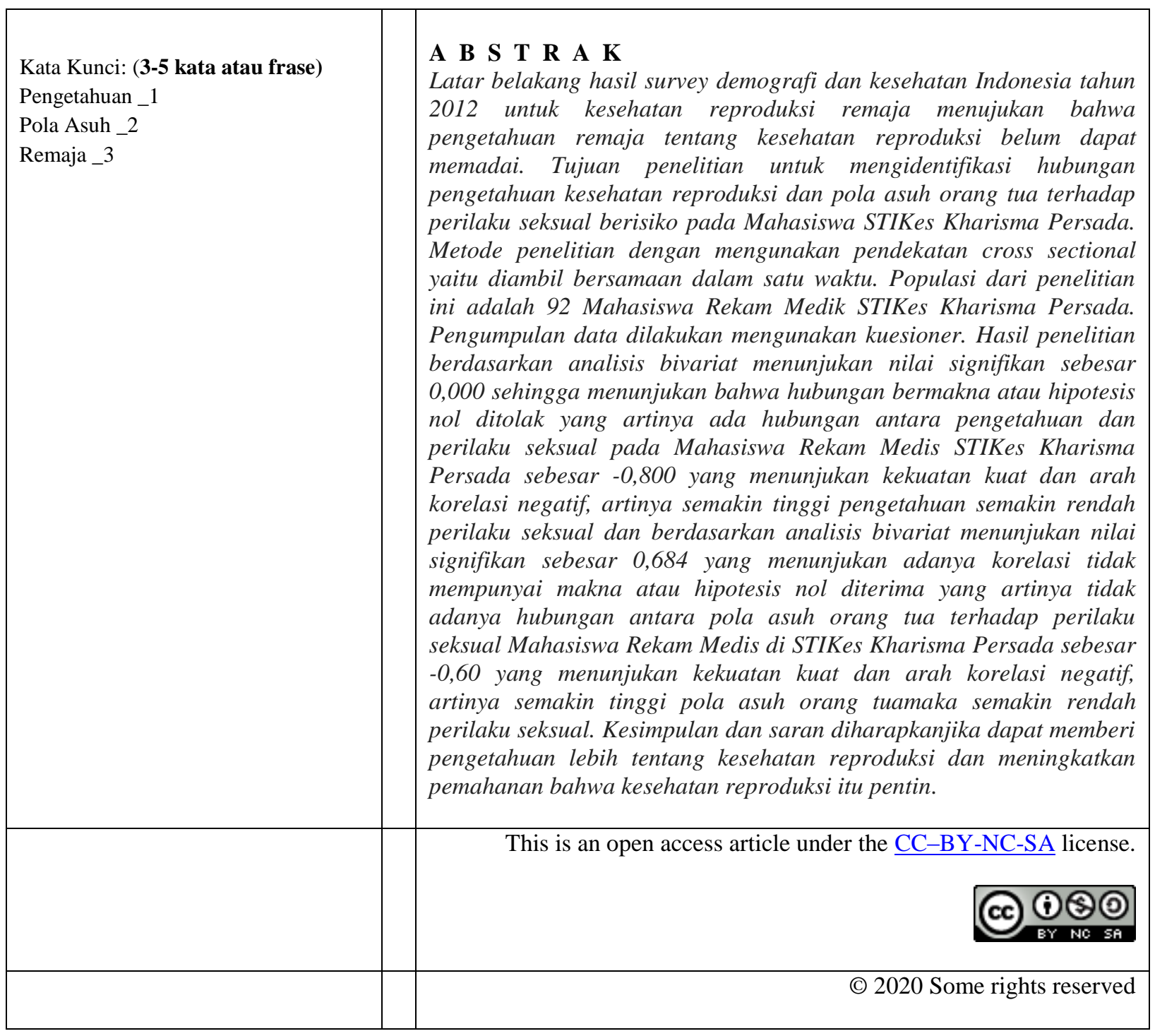




\section{PENDAHULUAN}

Menurut survei yang dilakukan pada Komisi Nasional Perlindungan Anak tentang perilaku berisiko pada remaja didapati data bahwa remaja yang sudah pernah menonton film porno sebanyak 97\%, remaja yang pernah berciuman, petting, dan oral sex sebesar $93,7 \%$, remaja yang masih berada pada tingkat perkuliahan yaitu mahasiswa mengaku pernah melakukan hubungan seksual sebesar $62,7 \%$, sedangkan $21,2 \%$ untuk mahasiswi sebesar pernah melakukan aborsi dan sisanya melakukan coitus (Putri dkk, 2012).

Terkait dengan fungsi reproduksi yang sudah mengalami perubahan, terdapat beberapa hal khusus terkait aktivitas seksual yang berdampak pada remaja yang meliputi: kehamilan remaja, infeksi menular seksual, dan HIV/AIDS (Allender dkk, 2014). Remaja yang mengalami pubertas lebih awal cenderung memiliki keinginan besar untuk melakukan aktivits seksual dan meningkatkan angka kejadian perilaku seksual berisiko.

Saat ini penyakit menular di Indonesia masih didominasi oleh HIV/AIDS. Adanya peningkatan kasus HIV yang terjadi pada penduduk usia 15-49 tahun, sejak tahun 2009 sampai 2013 dengan data prevalensi HIV $0,16 \%$ hingga mencapai $0,43 \%$ di tahun 2013. Data juga menyebutkan kasus dimana $30 \%$ atau sekitar 10.203 remaja terinfeksi HIV dengan rentang waktu 3 bulan (RISKESDAS, 2013).

Dari data presentanse puskesmas yang melakukan kegiatan kesehatan remaja menurut provinsi tahun 2015 didapati presentase $64,7 \%$ untuk provinsi Banten yang dimana data tersebut melebihi target renstra, jika dibandingkan dengan Provinsi DKI Jakarta mencapai 12,94\% (Kementrian Kesehatan RI, Profil Kesehatan Indonesia 2015, 2016). Banyaknya program-program peningkatan pengetahuan kesehatan reproduksi remaja di Provinsi Banten yang diperoleh dari data puskesmas yang mengampu tata laksana PKPR menunjukan bahwa kebutuhan konseling remaja dapat terpenuhi namun data menunjukan masih didapatkan remaja yang berperilaku berisiko yang terjadi di wilayah Tangerang khususnya di SMA swasta

\section{METODE PENELITIAN}

Penelitian ini yaitu mengambil desain penelitian deskriptif dengan memberi gambaran atau mendeskripsikan suatu kejadian atau objek secara objektif (Arikunto, 2014). Metode jenis penelitian cross sectional digunakan dalam penelitian ini yaitu dengan mengambil sampel secara 
bersamaan. Dengan menentukan variabel yang digunakan, maka tidak bisa dikatakan sebagai variabel jika variabel tidak ada variasinya. Agar dapat bervariasi maka suatu penelitian harus didasarkan terhadap kelompok atau sumber data serta objek yang bermacam-macam.

\section{HASIL}

Penelitian ini dilakukan pada tanggal 28 Juli 2019 dengan membagikan kuesioner pada Mahasiswa Rekam Medis di STIKes Kharisma Persada, untuk mengetahi apakah ada hubungan pengetahuan dan pola asuh orang tua terhadap perilaku seksual pada mahasiswa dapat dilihat pada tabel distribusi frekuensi sebagai berikut :

\section{ANALISIS UNIVARIAT}

Tabel 1.Distribusi Frekuensi Responden Berdasarkan Umur Mahasiswa Rekam Medis Di STIKes Kharisma Persada

\begin{tabular}{llll}
\hline No. & Kategori & Frekuensi & Presentase \\
\hline 1. & Laki-laki & 9 & 18,8 \\
\hline 2. & Perempuan & 39 & 81,2 \\
\hline & Total & 48 & 100,0
\end{tabular}

Berdasarkan tabel 1 diketahui hubungan pengetahuan dan pola asuh orang tua terdadap perilaku seksual berdasarkan karakteristik umur denganumur 19 tahun sebanyak 3 orang $(6,3 \%)$, umur 20 tahun sebanyak 10 orang $(20,8 \%)$, umur 21 tahun sebanyak 15 orang $(31,3 \%)$ dan umur 22 tahun sebanyak 20 orang $(41,7 \%)$.

Tabel 2.Distribusi Frekuensi Responden Berdasarkan Jenis Kelamin Mahasiswa Rekam Medis Di STIKes Kharisma Persada

\begin{tabular}{llll}
\hline No. & Kategori & Frekuensi & Persentase \\
\hline 1. & 19 tahun & 3 & 6,3 \\
\hline 2. & 20 tahun & 10 & 20,8 \\
\hline 3. & 21 tahun & 15 & 31,3 \\
\hline 4. & 22 tahun & 20 & 41,6 \\
\hline & Total & 48 & 100.0 \\
\hline
\end{tabular}

Berdasarkan tabel diatas 2 diketahui hubungan pengetahuan dan pola asuh orang tua terdadap perilaku seksual berdasarkan karakteristik jenis kelamin dengan responden berjenis kelamin lakilaki sebanyak 9 orang $(18,8 \%)$ dan sebagian besar responden berjenis kelamin perempuan sebanyak 39 orang $(81,3 \%)$.

Tabel 3. Distribusi Frekuensi Responden Berdasarkan Pengetahuan Mahasiswa Rekam Medis Di STIKes Kharisma Persada

\begin{tabular}{llll}
\hline No. & Kategori & Frekuensi & Presentase \\
\hline 1. & Baik & 35 & 72,9 \\
\hline 2. & Cukup & 9 & 18,8 \\
\hline 3. & Kurang & 4 & 8,3 \\
\hline & Total & 48 & 100,0 \\
\hline
\end{tabular}


Berdasarkan tabel 3 diketahui bahwa hubungan pengetahuan dan pola asuh terhadap perilaku seksualberdasarkan pengetahuanbaik sebanyak 35 orang (72,9\%), berpengetahuan cukup sebanyak 9 orang $(18,8 \%)$ dan berpengetahuan rendah 4 orang $(8,3 \%)$.

Tabel 4.Distribusi Frekuensi Responden Berdasarkan Pola Asuh Orang Tua Mahasiswa Rekam Medis Di STIKes Kharisma Persada

\begin{tabular}{llll}
\hline $\mathrm{N}$ & Kategori & $\begin{array}{l}\text { Frekuens } \\
\mathrm{i}\end{array}$ & Presentase \\
\hline 1 & Authoritarian & 1 & 2,1 \\
. & & & \\
\hline 2 & Autoritative & 47 & 97,9 \\
. & & & \\
\hline & Jumlah & 48 & 100,0 \\
\hline
\end{tabular}

Berdasarkan tabel 4 diketahui hubungan pengetahuan dan pola asuh orang tua terhadap perilaku seksual berdasarkan pola asuh orang tua hampir tidak ada responden dengan pola asuh auhtoritarian sebanyak 1 responden $(2,1 \%)$ dan hampir seluruhnya responden dengan pola asuh authoritative sebanyak 47 responden $(97,9 \%)$.

Tabel 5. Distribusi Frekuensi Responden Berdasarkan Perilaku Mahasiswa Rekam Medis Di STIKes Kharisma Persada

\begin{tabular}{llll}
\hline No. & Kategori & Frekuensi & Presentase \\
\hline 1. & Berisiko & 7 & 14,6 \\
\hline 2. & $\begin{array}{l}\text { Tidak } \\
\text { berisiko }\end{array}$ & 41 & 85,4 \\
\hline & Total & 48 & 100,0 \\
\hline
\end{tabular}

Berdasarkan tabel 5 diketahui bahwa hubungan pengetahuan dan pola asuh orang tua terhadap perilaku seksual berdasarkan perilaku sebagian kecil responden adalah berisiko sebanyak 7 orang $(14,6 \%)$ dan sebagian besar responden adalah tidak berisiko sebanyak 41 orang $(85,4 \%)$.

\section{ANALISIS BIVARIAT}

Tabel 6. Hasil Crosstabulation dan Uji Korelasi Spearman Rank (Rho) Hubungan Pengetahuan terhadap Perilaku Seksual pada Mahasiswa Rekam Medis di STIKes Kharisma Persada

\begin{tabular}{|c|c|c|c|c|c|c|c|c|}
\hline \multirow{3}{*}{ Pengetahuan } & \multicolumn{4}{|c|}{ Perilaku Seksual } & \multirow{2}{*}{\multicolumn{2}{|c|}{ Total }} & \multirow[b]{2}{*}{$\rho$} & \multirow[b]{2}{*}{$\mathrm{r}$} \\
\hline & \multicolumn{2}{|c|}{ Berisiko } & \multicolumn{2}{|c|}{$\begin{array}{l}\text { Tidak } \\
\text { Berisiko }\end{array}$} & & & & \\
\hline & $\mathrm{n}$ & $\%$ & $\mathrm{n}$ & $\%$ & $\mathrm{~N}$ & $\%$ & 0,000 & $-0,800$ \\
\hline baik & 0 & 0 & 35 & 72,9 & 35 & 72,9 & & \\
\hline Cukup & 3 & 6,3 & 6 & 12,5 & 9 & 18,8 & & \\
\hline Kurang & 4 & 8,3 & 0 & 0 & 4 & 8,3 & & \\
\hline Total & 7 & 14,6 & 41 & 85,4 & 48 & 100 & & \\
\hline
\end{tabular}


Berdasarkan tabel 6 menunjukkan bahwa responden dengan pengetahuan baik yang memiliki perilaku seksual tidak berisiko sebanyak 35 responden $(72,9 \%)$ dan didapati 3 responden $(6,3 \%)$ dengan pengetahuan cukup yang memiliki perilaku seksual berisiko.

Berdasarkan tabel 4.6 menunjukan nilai signifikan sebesar $0,000 \quad$ yang menunjukan bahwa hubungan bermakna atau juga hipotesis nol ditolak yang artinya menunjukan adanya hubungan antara pengetahuan dan perilaku seksual pada mahasiswa rekam medis STIKes Kharisma Persada sebesar $-0,800$ yang menunjukan kekuatan kuat dan arah korelasi negatif, artinya semakin tinggi pengetahuan maka semakin rendah perilaku seksual.

Tabel 7. Hasil Crosstabulation dan Uji Korelasi Spearman Rank (Rho) Hubungan Pola Asuh Orang Tua terhadap Perilaku Seksual pada Mahasiswa Rekam Medis di STIKes Kharisma Persada

\begin{tabular}{|c|c|c|c|c|c|c|c|c|c|}
\hline \multirow{3}{*}{ Pola Asuh } & \multicolumn{4}{|c|}{ Perilaku Seksual } & & & \multirow{3}{*}{$\mathrm{P}$} & \multirow{3}{*}{$\mathrm{r}$} & \multirow{3}{*}{ Keterangan } \\
\hline & \multicolumn{2}{|c|}{ berisiko } & \multicolumn{2}{|c|}{$\begin{array}{l}\text { Tidak } \\
\text { berisiko }\end{array}$} & \multicolumn{2}{|c|}{ Total } & & & \\
\hline & $\mathrm{n}$ & $\%$ & $\mathrm{n}$ & $\%$ & $\mathrm{~N}$ & $\%$ & & & \\
\hline Authoritarian & 0 & 0 & 1 & 2,1 & 1 & 2,1 & 0,684 & $-0,60$ & Korelasi \\
\hline Authoritative & 7 & 14,6 & 40 & 83,3 & 47 & 97,9 & & & signifikan \\
\hline Total & 7 & 14,6 & 41 & 85,4 & 48 & 100 & & & $\begin{array}{l}\text { kuat, kolerasi } \\
\text { negatif }\end{array}$ \\
\hline
\end{tabular}

Berdasarkan tabel 7 menunjukan bahwa responden dengan pola asuh authoritative yang memiliki perilaku tidak berisiko sebanyak 40 responden $(83,3 \%)$ dan pola asuh authoritarian yang memiliki perilaku tidak berisiko sebanyak 1 responden $(2,1 \%)$.

Berdasarkan tabel .7 menunjukan nilai signifikan sebesar 0,684 sehingga menunjukan bahwa korelasi tidak mempunyai makna atau hipotesis nol diterima yang berarti tidak adanya hubungan antara pola asuh orang tua terhadap perilaku seksual mahasiswa rekam medis di STIKes Kharisma Persada sebesar -0,60 yang menunjukan kuatan kuat dan arah hubungan negatif, artinya semakin tinggi pola asuh orang tua maka akan semakin rendah perilaku seksual. 


\section{PEMBAHASAN}

\section{ANALISIS UNIVARIAT}

a. Umur.

Berdasarkan analisis univariat didapatkan data umur 19 tahun sebanyak 3 orang $(6,3 \%)$, umur 20 tahun sebanyak 10 orang $(20,8 \%)$, umur 21 tahun sebanyak 15 orang $(31,3 \%)$ dan mayoritas responden berumur 22 tahun sebanyak 20 orang $(41,7 \%)$. Hal ini sesuai dengan teori Sarwono (2010) yaitu usia 19-22 tahun merupakan masa remaja akhir yang memiliki ciri khas diantaranya; pengakuan identitas diri, mampu selektif dalam mencari teman sebaya, mempunyai citra jasmani akan dirinya, mampu mewujudkan rasa cinta, dan mampu berpikir secara abstrak.

Hasil penelitian ini tidak selaras dengan penelitian menurut Nur Gilang Fitriana (2017) bahwa umur 14-16 tahun dapat dikatakan masa remaja pertengahan, sehingga saat usia tersebut remaja sangat rentan dengan pergaulan bebas serta bias lebih mudah untuk menerima informasi dari luar dan dapat disimpulkan bahwa tingkatan umur dapat mempengaruhi perilaku seksual pada remaja.

b. Jenis Kelamin
Berdasarkan analisis univariat dengan responden berjenis kelamin laki-laki sebanyak 9 orang $(18,8 \%)$ dan mayoritas responden berjenis kelamin perempuan sebanyak 39 orang $(81,3 \%)$. Hal ini sesuai teori menurut Sarwono (2010) perkembangan fisik dibagi menjadi 2 yaitu dengan ciri-ciri, yaitu seks primer maupun seks sekunder.

Hasil penelitian ini tidak sama dengan penelitian menurut Lathifah 'Arub (2017) berdasarkan penelitian ini yaitu responden yang berjenis kelamin lakilaki menjadi angka tertinggi dalam perilaku seksual berisiko. Sehingga pada penelitian ini didapatkan bahwa perilaku seksual pada remaja tidak tergantung pada jenis kelamin.

c. Pengetahuan

Berdasarkan analisis univariat didapatkan hasil mayoritas responden berpengetahuan baik sebanyak 35 orang $(72,9 \%)$, berpengetahuan cukup sebanyak 9 orang $(18,8 \%)$ dan berpengetahuan rendah 4 orang $(8,3 \%)$. Hal ini sejalan dengan teori menurut Fitriani (2011) pengetahuan adalah bentuk hasil dari suatu proses pembelajaran sesorang terhadap sesuatu baik itu yang dapat didengar maupun dilihat. 
Hasil penelitian ini senada dengan penelitian menurut Nur Gilang Fitriana (2017) bahwa pengetahuan baik yang peneliti dimaksudkan adalah responden paling mengerti dan paham mengenai seksual pranikah, dan dapat disimpulkan semakin tinggi pengetahuan remaja maka perilaku berisiko seksual semakin rendah

d. Pola Asuh Orang Tua

Berdasarkan analisis univariat didapatkan hampir tidak ada responden dengan pola asuh auhtoritarian sebanyak 1 responden $(2,1 \%)$ dan hampir seluruhnya responden dengan pola asuh authoritative sebanyak 47 responden (97,9\%). Hal ini sesuai teori Posey (2014) pola asuh authoritative menuntut kebebasan dan authoritarian cara orang tua mengasuh anak dengan menetapkan standar perilaku.

Hasil penelitian ini sejalan dengan penelitian menurut Nur Gilang Fitriana (2017) pada penelitian ini pola asuh orang tua yang baik dalam mendidik dan memberikan pola asuh yang baik terhadap anak atau remaja. Jadi pola asuh authoritative adalah pola asuh yang membesaskan anaknya dalam memilih sesuai dengan kehendaknya.

e. Perilaku seksual

Berdasarkan analisis univariat dengan hasil responden berisiko sebanyak 7 orang $(14,6 \%)$ dan sebagian besar responden tidak berisiko sebanyak 41 orang $(85,4 \%)$. Hal ini sesuai dengan teori Soetjiningsih (2014) Perilaku seksual remaja biasanya dipengaruhi oleh rasa sayang dan cinta serta perasaan bergairah yang tinggi kepada masing-masing pasangannya tanpa disertai komitmen yang jelas.

Hasil penelitian ini sejalan dengan penelitian menurut Lora Triana Marlita (2019) perilaku seksual merupakan sesuatu yang dianggap mempengaruhi perilaku harga diri seseorang, hubungan orang tua dengan anak, kecenderungan mencari sensasi seksual, keberadaan teman sebaya yang dapat menyimpang, dan penggunaan media pornografi. Dapat disimpulkan bahwa banyak faktor yang mempengaruhi perilaku seksual pada remaja.

\section{ANALISIS BIVARIAT}

a. Hubungan Pengetahuan dengan Perilaku Seksual Mahasiswa Rekam Medis Di STIKes Kharisma Persada Tahun 2019. 
Berdasarkan analisis bivariat Berdasarkan analisis bivariat menunjukan nilai signifikan sebesar 0,000 angka tersebut menunjukan bahwa hubungan bermakna atau hipotesis nol ditolak sehingga ada hubungan antara pengetahuan dan perilaku seksual pada mahasiswa rekam medis STIKes Kharisma Persada sebesar $-0,800$ yang menunjukan kekuatan kuat dan arah korelasi negatif, artinya semakin tinggi pengetahuan semakin rendah perilaku seksual. Pengetahuan yang di miliki seseorang merupakan faktor yang sangat penting untuk pembentukan tindakan seseorang hal ini sesuai dengan teori Mubarak (2012) .

Hasil penelitian ini sejalan dengan penelitian yang dilakukan oleh Nur Gilang Fitriana (2017) menunjukan bahwa pengetahuan cukup tentang seks pranikah di sini mempunyai pengaruh lebih besar terhadap kejadian perilaku seksual. Maka remaja yang memiliki pengetahuan lebih tinggi akan memiliki perilaku seksual yang rendah dan sebaliknya.

b. Hubungan Pola Asuh Orang Tua dengan Perilaku Seksual Mahasiswa Rekam Medis Di STIKes Kharisma Persada Tahun 2019

menunjukan nilai signifikan sebesar 0,684 angka ini menunjukan bahwa hubungan tidak bermakna atau hipotesis nol diterima yang berarti tidak adanya hubungan antara pola asuh orang tua terhadap perilaku seksual Mahasiswa Rekam Medis di STIKes Kharisma Persada sebesar -0,60 yang menunjukan kekuatan kuat dan arah hubungan negatif, yang artinya semakin tinggi pola asuh orang tua maka semakin rendah perilaku seksual. Pernyataan ini sesuai dengan Newman (2008) Perilaku berisiko yang dilakukan remaja dipengaruhi oleh perilaku orang tua dalam kehidupan sehari-hari yang berkontribusi sebagai role model bagi pembentukan karakter remaja.

Didapati hasil yang tidak sejalan, menurut penelitian Lora Triana Marlita (2019) tidak adanya hubungan pola asuh orang tua dengan perilaku seksual. Jadi seorang remaja dengan perhatian orang tua yang utuh akan menghindari perilaku seksual dan remaja dengan orang tua yang bercerai atau tidak utuh cenderung melakukan perilaku seksual.

\section{KESIMPULAN}

1. Teridentifikasinya nilai yang signifikan sebesar 0,000 hal ini 
menunjukan korelasi bermakna atau hipotesis nol ditolak sehingga adanya hubungan antara pengetahuan dan perilaku seksual pada mahasiswa rekam medis STIKes Kharisma Persada sebesar $-0,800$ yang menunjukan kekuatan kuat dan arah hubungan negatif, yang artinya semakin tinggi pengetahuan maka akan semakin rendah perilaku seksual.

2. Teridentifikasinya nilai signifikan sebesar 0,684 angka tersebut menunjukan yaitu hubungan tidak bermakna atau hipotesis nol diterima maka tidak ada hubungan antara pola asuh orang tua terhadap perilaku seksual mahasiswa rekam medis di STIKes Kharisma Persada sebesar 0,60 yang menunjukan kuatan kuat dan arah korelasi negatif, artinya semakin tinggi pola asuh orang tua maka akan semakin rendah perilaku seksual.

\section{DAFTAR PUSTAKA}

Allender, J., Rector, C., \&Warner, K. D (2014). Community Health Nursing; Promoting and Protecling The Public's Health (8th ed). Philadelphia: Lippincott Williams \& wilkins.

Arikunto, Suharsimi. (2013). Prosedur
Suatu Pendekatan Praktek. Jakarta : Rineka Cipta.

Arikunto, Suharsimi. (2014). Metodologi Penelitian dan pendekatan praktik.Jakarta: Rineka cipta

Baumrind. D. (2015). The influence of parenting style on adolescent competence and substance use. The journal of early adolescence February, 1(1), 56-59.

BKKBN, BPS, \& Kementrian Kesehatan. (2013). Survey Demografi dan Kesehatan Indonesia 2012. Kesehatan Reproduksi Remaja.

Boyd, D., Johnson, P., \& Bee, H. (2015). Lifespan Development (5th ed). USA: Pearson Canada Inc.

Brooks, J. B (2009). The process of parenting. Seventh Edition. USA: McGrawHill.

Dahlan, M.S. (2015). Statistik Untuk Kedokteran Dan Kesehatan. Jakarta : Salemba Medika.

Fitriani, Sinta. (2011). Promosi Kesehatan. Yogyakarta : Graha Ilmu.

Hasan, Mochammad (2014). Mutu Layanan Akademik Pendidikan Tinggi Kebidanan di Jawa Barat ( Studi tentang Pengaruh Motivasi, Prilaku Visioner dan Gaya Kepemimpinan Terhadap Prilaku Kepemimpinan. Visioner dan Mutu Layanan Akademik Perguruan Tinggi Akademik) disertai Sekolah Pasca Sarjana Universitas Pendidikan Indonesia.

Hidayat, Abdul aziz.(2014). Metodelogi Penelitian kesehatan.Jakarta : Salemba Medika 
Hurlock. (2009). Psokologi Perkembangan: Suatu Pendekatan Sepanjang Rentang Kehidupan (5 ed.). Yogyakarta: Penerbit Erlangga.

Kurniawati, dkk. Hubungan Antara Pola Asuh Orang Tua dengan Perkembangan Anak Toddler (Usia 1-3 Tahun) di Kelurahan Bener Kecamatan Wiradesa Kabupaten Pekalongan. 2011

Leiros, V. S., Carvalho, j., \& Nobre, P, (2016). Early parenting styles and sexual offending behavior; A comparative study. International journal of law and psychiatry, 46, 103-109, doi:10.1016/j.ijlp.2016.02.042

Mubarak, Wahit. (2012). Metodologi Penelitian Untuk Kebidanan. Jakarta : Salemba Medika.

Muthmainnah, (2012). Peran Orang Tua Dalam Menumbuhkan Pribadi Anak yang Androgynius Melakui Kegiatan Bermain. PGPAUD FIP Universitas Negeri Yogyakarta.

Norbu, K., Mukhia, S., \& Tshokey. (2013). Assessment of Knowledge on Sexually Transmitted Infections and sexual risk Behavior in Two Rural Districts of Bhutan. BMC Public Healt Journal, 13, 1142. Doi:10.1186/1471-2458-13-1142

Notoatmodjo, S. 2012. Metodelogi penelitian Kesehatan. Jakarta : Rienka Cipta.

Posey, B. M. (2014). The Effect of Parenting Styles on Substance Use and Academic Achievement Among Delinquent Youth: Implications for Selective Intervention Practices, Arizona State University.
Potter, P., Perry, A. (2009). Fundamental Keperawatan (7th ed., Vol. 1). (D. Sjabana, Ed., \& A. frederika, Trans.) Jakarta: Penerbit Salemba Medika.

Putri, P., \& (2012). Hubungan Peer Group Perilaku Seksual Remaja Di SMA Negeri 103 Jakarta Timur. Jakarta ; Universitas Indonesia

RISKESDAS. (2013). Riset Kesehatan Dasar 2013, Jakarta : Kemenkes RI

Santrock, J. (2010). Remaja (11 ed), (W. Hardani, Ed., \& B. Widyasinta, Trans.). Jakarta : Penerbit Erlangga.

Soetjiningsih. (2014). Tumbuh Kembang Remaja dan Permasalahannya. Jakarta : CV. Sagung Seto.

Sarwono, S. (2010). Psikologi Remaja. Jakarta : PT.Raja Grafindo Persada.

Sugiyono (2011). Metode Penelitian Kuantitatif dab $\mathrm{R}$ dan. Bandung : Alfabeta.

BKKBN. (2017). BKKBN Banten. Retrieved Maret 22, 2017, from BKKBN.go.id:http//banten.bkkbn.go .id/ViewBerita.aspx?BeritaID=852

Hubungan Pengetahuan Tentang Seks Pranikah Dengan Peilaku Seksual Pada Siswa SMK XX Semarang 2017. Nur Gilang Fitriana. Diakses pada tanggal 24 Juni 2019 didapat dari http://e-journal.akbid purworejo.ac.id/index.php/jkk4/articl e/view/59

Hubungan Pola Asuh Orang Tua Dengan Perilaku Seksual Remaja di SMK Negeri 1 Sewon Bantul 2017. Lathifah 'Arub. Diakses pada tanggal 24 Juni 2019. Didapat dari http://digilib.unisayogya.ac.id/2746/ 
Hubungan Pola Asuh Orang Tua Dengan Perilaku Seksual Remaja Di SMK Teknologi Migas Pekanbaru 2019. Lora Triana Marlita. Diakses pada tanggal 24 Juni 2019. Didapat dari http://jurnal.univrab.ac.id/index.php/ keperawatan/article/view/506 